\title{
Mineralogical, textural and physical-mechanical study of hydraulic lime mortars cured under different moisture conditions
}

\author{
A. Arizzi $₫$, G. Martinez-Huerga, E. Sebastián-Pardo, G. Cultrone \\ Universidad de Granada (Granada, España) \\ \anna.arizzi@ouce.ox.ac.uk
}

Received 4 June 2014

Accepted 9 December 2014

Available on line 7 A pril 2015

\begin{abstract}
This work focuses on the chemical-mineralogical, textural and physical-mechanical properties of hydraulic lime mortars made with siliceous and calcareous aggregate. Mortars were cured at $60 \%$ and $90 \%$ of relative humidity, so as to assess the variability of mortar petrophysical properties in the hardened state due to the moisture conditions. The final aim was to determine the most adequate moisture conditions to be maintained during application and hardening of hydraulic mortars intended for repair interventions. We found out that using a calcareous aggregate and curing mortar at $90 \%$ of relative humidity give place to better textural and mechanical properties. However, these characteristics mostly depend on the maximum size of the aggregate grains, which should be smaller than $6 \mathrm{~mm}$, in order to avoid the occurrence of mechanical discontinuities in the mortar.
\end{abstract}

KEYWORDS: Mortar; Curing; Carbonation; Calcium silicate hydrate (C-S-H); Characterization

Citation/Citar como: Arizzi, A.; Martínez- Huerga, G.; Sebastian-Pardo, E.; Cultrone, G. (2015) Mineralogical, textural and physical-mechanical study of hydraulic lime mortars cured under different moisture conditions. Mater. Construcc. 65 [318], e053 http://dx.doi.org/10.3989/mc.2015.03514.

RESUMEN: Estudio mineralógico, textural y físico-mecánico de morteros de cal hidráulica curados en distintas condiciones de humedad relativa. En este trabajo se han estudiado las propiedades químico-mineralógicas, texturales y físico-mecánicas de morteros de cal hidráulica elaborados con áridos silíceo y calcítico. Estos morteros se han curado al 60\% y 90\% de humedad relativa, con el fin de evaluar las eventuales diferencias en las propiedades petrofísicas de los morteros una vez endurecidos y así establecer cuál de los dos ambientes es recomendable durante la aplicación y fraguado de morteros de cal hidráulica destinados a obras de restauración. Se ha encontrado que el uso de un árido de composición calcítica y el curado al 90\% de humedad relativa dan lugar a morteros hidráulicos con mejores características texturales y propiedades mecánicas. De todas formas, estas características dependen principalmente del tamaño máximo del árido empleado, que debería ser inferior a $6 \mathrm{~mm}$ para evitar discontinuidades mecánicas en el mortero.

PALABRAS CLAVE: Mortero; Curado; Carbonatación; Silicatos cálcicos hidratados (C-S-H); Caracterización

Copyright: (C) 2015 CSIC. This is an open-access article distributed under the terms of the Creative Commons Attribution-Non Commercial (by-nc) Spain 3.0 License.

\section{INTRODUCTION}

The UNE EN 459-1 European standard (1) classifies limes according to several criteria, among them: hardening process, chemical composition and physical state. Following this classification, limes are grouped as: aerial (CL and DL) quicklime (-Q) or hydrated limes (-S), in the form of powder or putty (-PL), hydraulic limes (HL), natural hydraulic limes (NHL) and formulated limes (FL). Within these groups, however, there exists a huge variety of limes, depending on their chemical composition and 
physical state. Therefore, it can be hard to choose the most suitable lime for the production of a specific repair mortar. Discarding a priori the use of Portland cement, since it gives place to soluble salts $(2,3)$ and is incompatible (from a physical-mechanical point of view (4)) with other building materials (stone, brick, lime mortar), it is fundamental to know which are both the esthetical characteristics and the chemical-mineralogical, textural and physicalmechanical properties that the repair mortar must exhibit once in the building.

On the one hand, the use of an aerial lime in repair mortars is generally recommended for external and external applications, wall rendering (where it would act as a "sacrificial" layer), pointing and casting mortars, and preparation layers for decorative finishes or stucco. On the other hand, the use of an aerial lime mortar is not recommended in moist areas and its application is not appropriate in load-bearing parts of the building (as a structural mortar (4)). In the latter cases, a hydraulic lime mortar would be more adequate. There exist three main classes of hydraulic lime, depending on the compressive strength they confer to mortar: NHL2, feebly (slightly) hydraulic lime, produced from limestone containing under $12 \%$ clay; NHL3.5, moderately hydraulic lime, produced from limestone containing under $12 \%$ to $18 \%$ clay; and NHL5, eminently hydraulic lime, produced from limestone containing under $18 \%$ to $25 \%$ clay (5). Nowadays, the NHL3.5 is the most used hydraulic lime in repair works, especially for rendering in moist areas, repairing big surfaces of mortar or stone blocks, flooring, exc. (4). Generally, this lime is added to cement to improve mortar plasticity or used as the only binder to obtain mortars with lower shrinkage, higher mechanical strength and better durability with respect to aerial lime mortars (6).

Once chosen the type of lime, it is fundamental to take into account also the curing conditions to which the mortar is exposed since the first days after its application. The European standard defines the following optimal conditions of temperature and relative humidity for the curing of mortar samples in the laboratory (7): $\mathrm{T}=20 \pm 2{ }^{\circ} \mathrm{C}$ and $\mathrm{RH}=95 \pm 5 \%$ for the first 5 days in the mould and the following 2 days removed from the mould; $\mathrm{T}=20 \pm 2{ }^{\circ} \mathrm{C}$ and $\mathrm{RH}=65 \pm 5 \%$ for the following 21 days. These instructions are hard to be kept in the building and, sometimes, a wrong maintenance during the first hours or days can give place to an inappropriate behaviour of the mortar in the building (8). However, controlling the environmental conditions during the application of repair mortars is fundamental to avoid compromising the final quality of the material. Moreover, it has been demonstrated that the curing conditions also affect the effectiveness of pozzolanic additives in hydraulic lime mortars (9).
The aim of this work is to determine the influence of different curing environments on the hardening process (carbonation degree and hydrated phase formation) and, therefore, on the textural and physical-mechanical properties (porous system and mechanical strengths) of mortars produced with natural hydraulic lime (NHL3.5). This work is composed of the following steps: 1) chemicalmineralogical and textural study of the raw materials used in mortar production; 2) mortar preparation and curing under different relative humidity $(60 \%$ and $90 \%$ ) for the first 28 days; 3 ) mineralogical and textural analyses, mechanical tests, measurements of ultrasound propagation velocity and chromatic parameters on the hardened mortar samples and comparison of these properties at different moisture conditions, with the aim to select the most suitable curing environment for these materials.

\section{MATERIALS AND METHODS}

\subsection{Raw materials}

Mortars were prepared with a natural hydraulic lime NHL3.5 (1) in the form of powder, whose commercial name is i.design CALIX 3.5, produced (and supplied) by the FYM-Italcementi enterprise (Malaga, Spain, www.fym.es/ES).

Two natural aggregates with continuous grading were used: a standardized siliceous sand (SA) with a grading of $0.1<\phi<2 \mathrm{~mm}$ (10) of the Eduardo Torroja Institute (CSIC, Madrid, Spain) and a crushing calcareous aggregate $(\mathrm{CA}, 0<\phi<6 \mathrm{~mm})$ from the province of Granada.

The major and trace elements of the lime and the aggregate were analysed by means of a S4 PioneerBruker X-ray fluorescence (XRF) spectrometer with wavelength dispersion, equipped with $\mathrm{Rh} \mathrm{X}$-ray tube (60 kV, $150 \mathrm{~mA})$ and LIF200/PET/OVO-55 crystals. Samples were ground and the powder dispersed in $\mathrm{KBr}$ pellets before the analysis. The identification and semi-quantification of mineral phases was performed by X-ray diffraction (XRD, disoriented powder method), using a Panalytical X'Pert PRO MPD diffractometer, with automatic loader. Experimental conditions were: $45 \mathrm{kV}$ voltage and $40 \mathrm{~mA}$ current intensity; $\mathrm{CuK} \alpha$ radiation $(\lambda \approx 1.5405 \dot{\mathrm{A}}) ; 3$ to $70^{\circ} 2 \Theta$ explored area; $0.01^{\circ} 2 \Theta /$ s goniometer speed. Mineral phase identification was carried out using the X-Powder software package (11).

Table 1 shows the chemical and mineralogical composition of the hydraulic lime (NHL3.5) and the calcareous aggregate (CA). The natural hydraulic lime is mainly composed of portlandite and calcium $\left(\mathrm{CaSiO}_{3}\right)$ and di-calcium $\left(\mathrm{Ca}_{2} \mathrm{SiO}_{4}\right.$, belite $)$ silicates. Also a small amount of calcite was detected in the lime, as a result of a slight carbonation of portlandite, probably occurred due to air exposure during lime storing and preparation. The mineral composition 
TABLE 1. Dosages and characteristics of NHL-SA (NHL3.5 hydraulic lime and standardized silceous sand) and NHL-CA (NHL3.5 hydraulic lime and calcareous sand) mortars in the fresh state. $\mathrm{B} / \mathrm{S}=$ binder-to-sand ratio; $\mathrm{W} / \mathrm{B}=$ =water-to-binder ratio; vol.=ratio by volume; wt.=ratio by weight

\begin{tabular}{lcc}
\hline Mortar & NHL-SA & NHL-CA \\
\hline B/S (vol.) & $1: 3$ & $1: 3$ \\
B/S (wt.) & $1: 3$ & $1: 6$ \\
W/B (wt.) & 0.7 & 1.1 \\
Flow (mm) & 168 & 150 \\
Penetration (mm) & 121 & 121 \\
Trapped air (\%) & 4.4 & 2.3 \\
Water retention (mm) & 88.7 & 82.4 \\
Bulk density in the fresh state $\left(\mathrm{kg} / \mathrm{m}^{3}\right)$ & 2040 & 2129 \\
\hline
\end{tabular}

of the calcareous aggregate (mainly calcite and, in minor proportion, quartz and dolomite) is typical of the limestone extracted from the Sierra Elvira in Granada (12). It is fundamental to control the quantity of dolomite present in the aggregate, since this mineral phase can react with sulphates, forming soluble salts, harmful for the mortar and the other materials in the building (13). The chemical elements identified agree with the described mineralogy, being $\mathrm{CaO}$ the main oxide, in a quantity higher than $60 \%$ by weight. The siliceous aggregate (SA) has a $\mathrm{SiO}_{2}$ content $\geq 98 \%$ (10).

\subsection{Mortar production}

Mortar samples were prepared following the UNE-EN 1015-2 (14) standard, with some variations detailed hereinafter. Two types of natural hydraulic lime mortar were produced with siliceous standard sand (NHL-SA) and calcareous crushing aggregate (NHL-CA). These mortars were prepared with a 1:3 binder-to-aggregate dosage by volume, being this one of the most used $(15,16)$, whilst the amount of adding water was chosen according to the mortar consistency. Mortar binder-to-aggregate and waterto-binder dosages, flow values (17), penetration, trapped air, water shrinkage and bulk density (18) in the fresh state are shown in Table 2. After mixing (14), mortars were casted in standardized moulds $(40 \times 40 \times 160 \mathrm{~mm})$ and cured for 7 days in the mould and the following 21 days out of the mould (15), under controlled temperature $\left(\mathrm{T}=20 \pm 5^{\circ} \mathrm{C}\right)$ and relative humidity ( $\mathrm{RH}=60 \pm 5 \%$ and $90 \pm 5 \%$ ).

\subsection{Mortar characterization after 28 days of curing}

\subsubsection{Mineralogical study}

The mineralogical study was performed both in the surface and in the core of mortar samples, by means of XRD (using the same working conditions as
TABLE 2. Results of the chemical (by means of X-ray fluorescence, XRF) and mineralogical (by means of X-ray diffraction, XRD) analyses of the hydraulic lime (NHL3.5) and the calcareous aggregate (CA). LOI=loss on ignition; $\mathrm{Qtz}=$ quartz; $\mathrm{Cal}=$ calcite; $\mathrm{Dol}=$ dolomite; Port=portlandite; $\mathrm{CS}=$ calcium and di-calcium silicates. $* * *$ more than $80 \%$; ** between 40 and $50 \%$; $*$ less than $10 \%$

\begin{tabular}{|c|c|c|c|c|c|c|c|}
\hline \multicolumn{4}{|c|}{$\mathbf{C A}$} & \multicolumn{4}{|c|}{ NHL3.5 } \\
\hline \multicolumn{2}{|c|}{ XRF } & \multicolumn{2}{|c|}{ XRD } & \multicolumn{2}{|c|}{ XRF } & \multicolumn{2}{|c|}{ XRD } \\
\hline & $w t . \%$ & & & & $w t . \%$ & & \\
\hline $\mathrm{Na}_{2} \mathrm{O}$ & 0.039 & Qtz & $*$ & $\mathrm{Na}_{2} \mathrm{O}$ & 0.038 & Cal & $*$ \\
\hline $\mathrm{MgO}$ & 1.052 & Cal & $* * *$ & $\mathrm{MgO}$ & 2.618 & Port & $* *$ \\
\hline $\mathrm{Al}_{2} \mathrm{O}_{3}$ & 1.080 & Dol & $*$ & $\mathrm{Al}_{2} \mathrm{O}_{3}$ & 0.999 & CS & $* *$ \\
\hline $\mathrm{SiO}_{2}$ & 4.292 & & & $\mathrm{SiO}_{2}$ & 8.354 & & \\
\hline $\mathrm{CaO}$ & 62.170 & & & $\mathrm{CaO}$ & 65.683 & & \\
\hline $\mathrm{Fe}_{2} \mathrm{O}_{3}$ & 0.709 & & & $\mathrm{Fe}_{2} \mathrm{O}_{3}$ & 0.570 & & \\
\hline $\mathrm{K}_{2} \mathrm{O}$ & 0.386 & & & $\mathrm{~K}_{2} \mathrm{O}$ & 0.342 & & \\
\hline $\mathrm{P}_{2} \mathrm{O}_{5}$ & 0.043 & & & $\mathrm{P}_{2} \mathrm{O}_{5}$ & 0.030 & & \\
\hline $\mathrm{TiO}_{2}$ & 0.084 & & & $\mathrm{TiO}_{2}$ & 0.054 & & \\
\hline $\mathrm{MnO}$ & 0.012 & & & $\mathrm{MnO}$ & 0.011 & & \\
\hline & ppm & & & & ppm & & \\
\hline S & 233 & & & $S$ & 3545 & & \\
\hline $\mathrm{Cl}$ & 115 & & & $\mathrm{Cl}$ & 74 & & \\
\hline $\mathrm{Sr}$ & 268 & & & $\mathrm{Sr}$ & 1356 & & \\
\hline $\mathrm{Pb}$ & 0 & & & $\mathrm{~Pb}$ & 0 & & \\
\hline $\mathrm{Zn}$ & 34 & & & $\mathrm{Zn}$ & 0 & & \\
\hline $\mathrm{Cu}$ & 57 & & & $\mathrm{Cu}$ & 51 & & \\
\hline LOI & 30 & & & LOI & 6.19 & & \\
\hline
\end{tabular}

those described above) and thermal analysis (TGA). The latter was useful to confirm the data obtained by XRD, referring to the portlandite and calcite percentages of the different mortars, and to evaluate the amount of hydrated phases formed during hardening. Thermal measurements were performed by means of a SHIMADZU TGA-50H analyser, which worked in a $\mathrm{N}_{2}$ atmosphere, at a heating rate of $10{ }^{\circ} \mathrm{C} / \mathrm{min}$ over a range of $25-950^{\circ} \mathrm{C}$. Approximately $70 \mathrm{mg}$ of sample were ground before the analysis.

\subsubsection{Textural and porosity study}

Field emission scanning electron microscopy (FESEM) was used to observe the textural and morphological characteristics of mortars (crystal morphology and size, texture, adhesion between binder and aggregate). The evolution of carbonation and hydration was also studied from the observation of portlandite, carbonates and hydrated phases. For this study, a Carl Zeiss SMT AURIGA FESEM microscope was used. Samples were oven-dried at $70 \pm 5^{\circ} \mathrm{C}$ for 8 hours and then carbon-coated before the observation. Mortar porous system (total open porosity, pore size distribution, real and bulk densities) 
were studied by means of mercury intrusion porosimetry (MIP), in a range of pore radius comprised between 0.003 and $360 \mu \mathrm{m}$. Samples were oven-dried at $70 \pm 5^{\circ} \mathrm{C}$ for 8 hours and then analysed by means of a Micromeritics Autopore III 9410 porosimeter.

\subsubsection{Mechanical tests}

To study mortar mechanical properties, flexural and compressive tests were performed by means of a hydraulic press, following the UNE-EN 1015-11 standard (7). Flexural strength was measured on three samples; the six samples obtained after the flexural rupture were used for the compressive test. Strength values were calculated according to the following formula [1] to calculate the flexural strength:

$$
\mathrm{f}=\frac{1.5 F L}{b d^{2}}
$$

where $\mathrm{f}$ is the flexural strength (in $\mathrm{MPa}$ ), $\mathrm{F}$ is the load (in N), $\mathrm{L}$ is the distance between the support points (in mm), b is the sample width (in $\mathrm{mm}$ ) and $\mathrm{d}$ the sample thickness (in mm);

- to calculate the compressive strength [2]:

$$
\mathrm{c}=\frac{1.5 F 1000}{6400}
$$

where $\mathrm{c}$ is the compressive strength (in $\mathrm{MPa}$ ) and $\mathrm{F}$ is the load (in N).

After the flexural strength, samples were sprayed with a phenolphthalein dissolution ( $2 \%$ in ethanol) to visually assess the carbonation degree achieved after 28 days.

\subsubsection{Non-destructive tests}

The propagation velocity $\left(\mathrm{V}_{\mathrm{p}}\right)$ of ultrasounds through mortars was measured by means of a Panametrics HV Pulser/Receiver 5058 PR, with $500 \mathrm{~Hz}$ transducers, coupled to a Tektronix TDS 301 2B oscilloscope. The P (primary) wave propagation was performed along three directions, two parallel and one perpendicular to the mortar compaction plane. A Konica-Minolta CM-700d spectrophotometer was used to measure lightness, $\mathrm{L}^{*}$, and the coordinates of mortars, $\mathrm{a}^{*}$ and $\mathrm{b}^{*}$, according to the CIELab system. Also the whiteness (W) and the yellow indexes were calculated, referring to the control white of the instrument $(\mathrm{Z} / \mathrm{Zn} * 100)$. Working conditions were: $8 \mathrm{~mm}$ diameter of the measured area, D65 illuminant, $10^{\circ}$ view angle, SCI/SCE mode and 400-700 nm light radiation range. The colour was measured in 5 points of each mortar.

\section{RESULTS AND DISCUSSION}

\subsection{Mineralogical study of mortars}

The mineralogy of mortars, determined by means of XRD, and the percentage of each phase, calculated by means of XRD and TGA, are indicated in Table 3. The type of aggregate used influences the mineral composition. Approximately $80 \%$ of quartz was detected in NHL-SA mortars and a slightly higher quantity of calcite $(\sim 86 \%)$ in NHL-CA mortars, in addition to a small quantity of dolomite (Table 3 ) due to the presence of this phase in the limestone from which the CA aggregate proceeds (Table 1). Moreover, part of the calcite found in NHL-CA mortars proceeds not only from the aggregate but also from the carbonation of portlandite.

Although the two types of mortar were prepared with the same dosage by volume (1:3), converted in weight proportion, this corresponds to a lime-toaggregate dosage of 1:6 in NHL-CA mortar and of 1:3 in the NHL-SA one (Table 2). This means that the initial amount of lime is approximately $14 \%$ wt. in NHL-CA and 25\% wt. in NHL-SA on the total mass of samples, respectively. As a consequence, for each mortar type, half of this amount corresponds to the content of portlandite and the other half to the content of calcium silicates (each phase is present as a 7\% in NHL-CA and a $13 \%$ in NHL-SA mortars, considering the XRD results, Table 1). Taking into account these initial amounts in the two types of mortars, it is possible to estimate towards which process (carbonation or hydration) and in which conditions of relative humidity the two mortar types are more reactive, calculating the percentage of portlandite and calcium silicates that have reacted. In hydraulic lime mortars, one part of the lime (the calcium hydroxide) reacts with the atmospheric $\mathrm{CO}_{2}$ in the carbonation process that leads to the formation of calcite, whilst the other part (the calcium silicates) reacts with water, leading to the formation of hydrated phases. A bigger consumption of $\mathrm{Ca}(\mathrm{OH})_{2}$ with respect to the calcium silicates indicates a higher reactivity of the matrix towards the carbonation process and, vice versa, towards hydration.

The approximate amounts of portlandite $(\mathrm{CH})$ and calcium silicates (CS) that have reacted in the two types of mortars cured at $60 \%$ and $90 \%$ of relative humidity, calculated by means of TGA, are indicated in Table 3. Notwithstanding, it is important to take into account that, during the hydration of calcium silicates, calcium hydroxide is formed and this phase can either increase the portlandite content or the calcite one (if it carbonates). This percentage of newly-formed calcium hydroxide has not been taken into consideration in the quantitative analysis, due to the difficulty of determining it exactly. 
TABLE 3. Results of the X-ray diffraction (XRD) and thermal (TGA) analyses performed on the external (EX) and internal (IN) zones of mortars made with standardized siliceous (NHL-SA) and calcareous (NHL-CA) sand and cured at a relative humidity of 60\% (_60) and 90\% (_90). Cal=calcite; Por=portlandite; Qtz=quartz; Dol=dolomite; $\mathrm{CS}=$ calcium and di-calcium silicates; Port reac=percentage of reacted portlandite; $\mathrm{CS}$ reac $=$ percentage of reacted calcium and di-calcium silicates; $* * *=75-90 \% ; * *=5-10 \% ; *=1-4 \%$

\begin{tabular}{|c|c|c|c|c|c|c|c|c|}
\hline \multirow{2}{*}{$\begin{array}{l}\text { Mortar } \\
\text { Zone }\end{array}$} & \multicolumn{2}{|c|}{ NHL-SA_60 } & \multicolumn{2}{|c|}{ NHL-SA_90 } & \multicolumn{2}{|c|}{ NHL-CA_60 } & \multicolumn{2}{|c|}{ NHL-CA_90 } \\
\hline & EX & IN & EX & IN & EX & IN & EX & IN \\
\hline Cal & $* *$ & $*$ & $* *$ & $*$ & $* * *$ & $* * *$ & $* * *$ & $* * *$ \\
\hline Por & $* *$ & $* *$ & $* *$ & $* *$ & $*$ & $*$ & $* *$ & $* *$ \\
\hline Qtz & $* * *$ & $* * *$ & $* * *$ & $* * *$ & $*$ & $*$ & $*$ & $*$ \\
\hline Dol & - & - & - & - & $* *$ & $* *$ & $* *$ & $* *$ \\
\hline $\mathrm{CS}$ & $* *$ & $* *$ & $* *$ & $* *$ & $* *$ & $* *$ & $* *$ & $* *$ \\
\hline Port reac & $55-60$ & $20-25$ & $35-40$ & $20-25$ & $55-60$ & $55-60$ & $40-45$ & $40-45$ \\
\hline $\mathrm{CS}$ reac & $45-50$ & $25-30$ & $30-40$ & $40-50$ & $25-30$ & $10-15$ & $55-60$ & $40-45$ \\
\hline
\end{tabular}

As a consequence, the amount of portlandite $(\mathrm{CH})$ in Table 3 has been given approximately, as a range of values.

In NHL-SA mortars, the external zone is more reactive towards the carbonation process compared to the interior of samples, in both mortars cured at $60 \%$ and $90 \%$ of RH. In NHL-CA mortars, instead, carbonation occurred with similar velocity in both zones (almost the same amount of portlandite reacted in the core and the surface of mortar). Generally, carbonation is slower at $90 \%$ of relative humidity (a lower percentage of portlandite reacts) and this difference is evident especially in NHL-CA mortars.

It is worth considering that the quantification of hydraulic phases (calcium and di-calcium silicates and hydrated calcium silicates) by means of XRD is not accurate, since the amount of these phases is often lower than the resolution limit of this technique $(3-5 \%(19))$. For this reason, it is advisable to use complementary techniques for their determination. The formation of hydrated phases and, consequently, the transformation of calcium silicates, was evaluated comparing the height of the peaks obtained from the thermal decomposition of the calcium silicate hydrates $(\mathrm{C}-\mathrm{S}-\mathrm{H})$, which occurs between 110 and $225^{\circ} \mathrm{C} \mathrm{(20)}$ in the thermogravimetric curves (Figures 1 and 2). In these curves, the differential variation of weight due to the thermal decomposition of C-S-H (between 110 and $225^{\circ} \mathrm{C}$ ), portlandite $\left(\mathrm{CH}\right.$, between 300 and $\left.600{ }^{\circ} \mathrm{C}\right)$ and calcite $\left(\mathrm{CC}\right.$, between 550 and $\left.955^{\circ} \mathrm{C}\right)$, was represented as a function of temperature. The TG curves reflect the differences in the quantity of the three detected phases (C-S-H, CH and CC) depending on the type of aggregate (calcareous or siliceous), the analysed zone (exterior or interior) and the relative humidity $(60 \%$ or $90 \%)$

It is worth highlighting that the TG curves are also useful to understand the contribution of the newly-formed $\mathrm{Ca}(\mathrm{OH})_{2}$, since its content is proportional to the signal of the C-S-H. In all mortars cured at $60 \%$ of $\mathrm{RH}$ this contribution is very similar both between the external and internal part of each mortar and between the two mortar types. In mortars cured at $90 \%$ of $\mathrm{RH}$, instead, a larger peak corresponding to the C-S-H phases is detected in the internal sample of NHL-SA mortar. This may indicate a slightly greater content of newlyformed $\mathrm{Ca}(\mathrm{OH})_{2}$. The peak corresponding to the dehydroxilation of $\mathrm{Ca}(\mathrm{OH})_{2}$, in fact, is larger in this internal sample compared to the external one but it is not possible to know whether this is an effect of only the greater hydration or also a lower carbonation. However, if more calcium hydroxide was formed due to the CS hydration, this has not significantly contributed to the increase of calcium carbonate content in the mortar (as observed from the height of the peak corresponding to the $\mathrm{CaCO}_{3}$ decomposition in NHL-SA_90 IN, Figure 2).

In mortars cured at $60 \%$ (Figure 1), the height of the peak of C-S-H is very similar in both types of mortars, as well as in the external and internal zones, which indicates that a similar quantity of hydrated phases formed. The height of the same peak is larger in mortars cured at 90\% of RH (Figure 2), as hydration reactions are more favoured at higher relative humidity. Notwithstanding, small differences in the height of the peak of C-S-H were found between the two types of mortars. The internal zone of NHL-SA mortars cured at $90 \%$ of $\mathrm{RH}$ has a larger amount of hydrated phases compared to the external one (Figure 2). This is due to a higher humidity (water content) in the interior of samples, which favours the development of hydrated phases more than in the exterior, where water evaporates easier (due to exposure to air). In NHL-CA mortars cured at the same relative humidity, instead, the C-S-H amount is the same in the exterior and the interior of samples (Figure 2). 

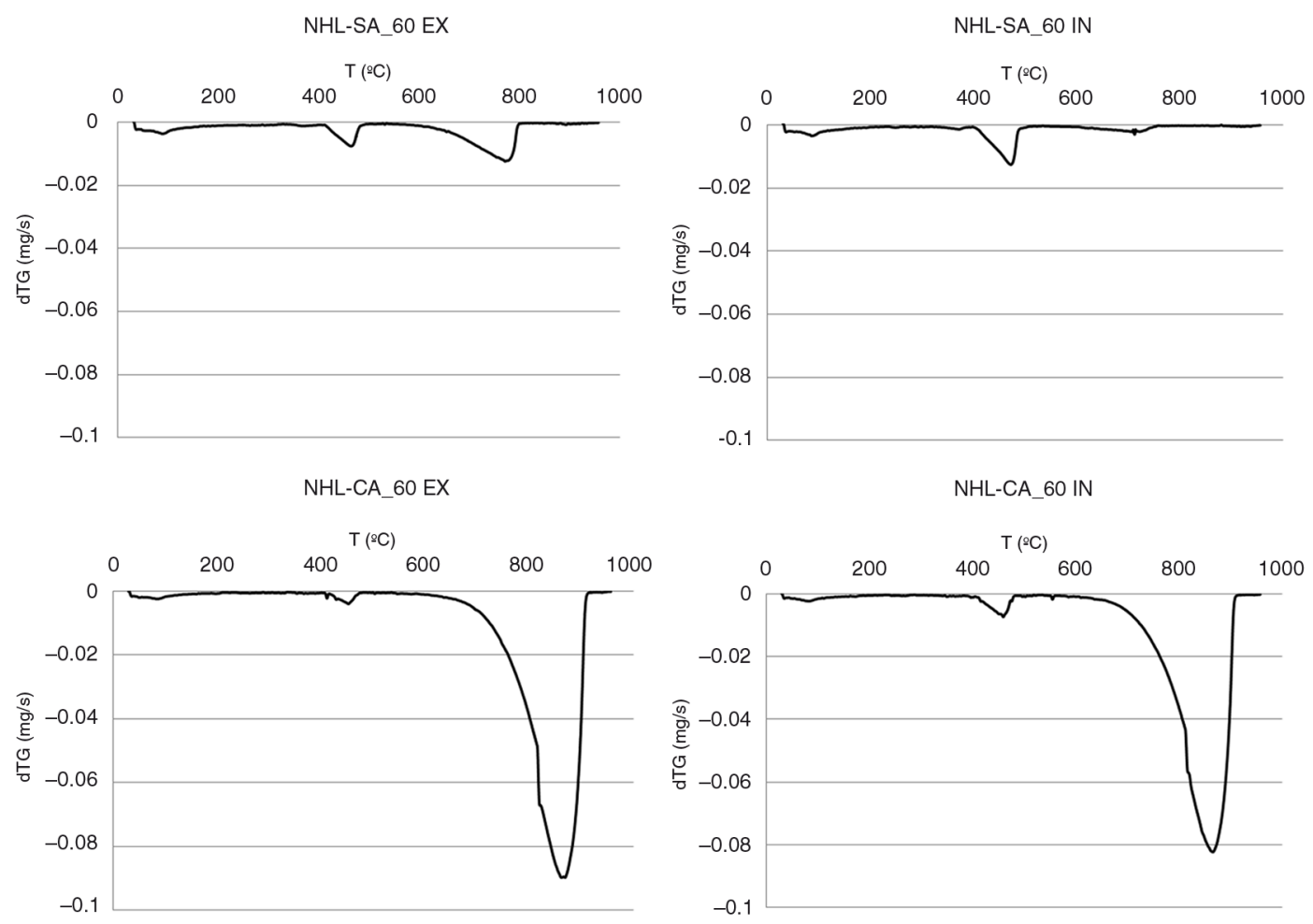

FIGURE 1. Differential thermal curves of the external (EX) and internal (IN) zones of mortars made with siliceous (NHL-SA) and calcareous (NHL-CA) sand and cured at a relative humidity of $60 \%\left(\_60\right)$, where the differential weight loss (dTG, in $\mathrm{mg} / \mathrm{s}$ ) has been represented as a function of the decomposition temperature $\left(\mathrm{T}\right.$, in $\left.{ }^{\circ} \mathrm{C}\right)$.
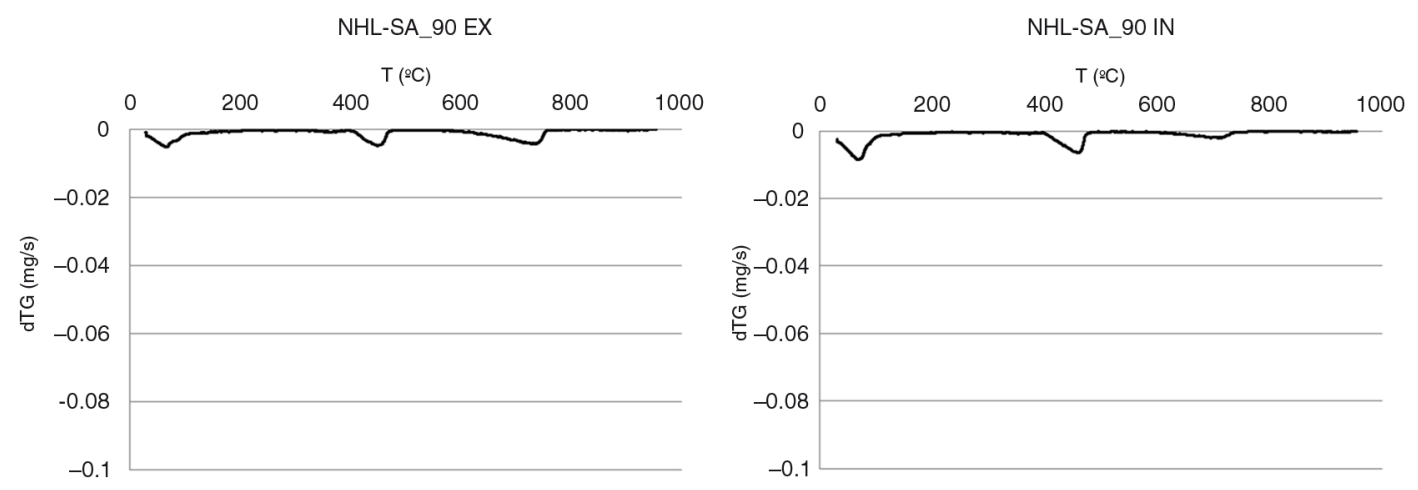

NHL-CA_90 EX

NHL-CA_90 IN
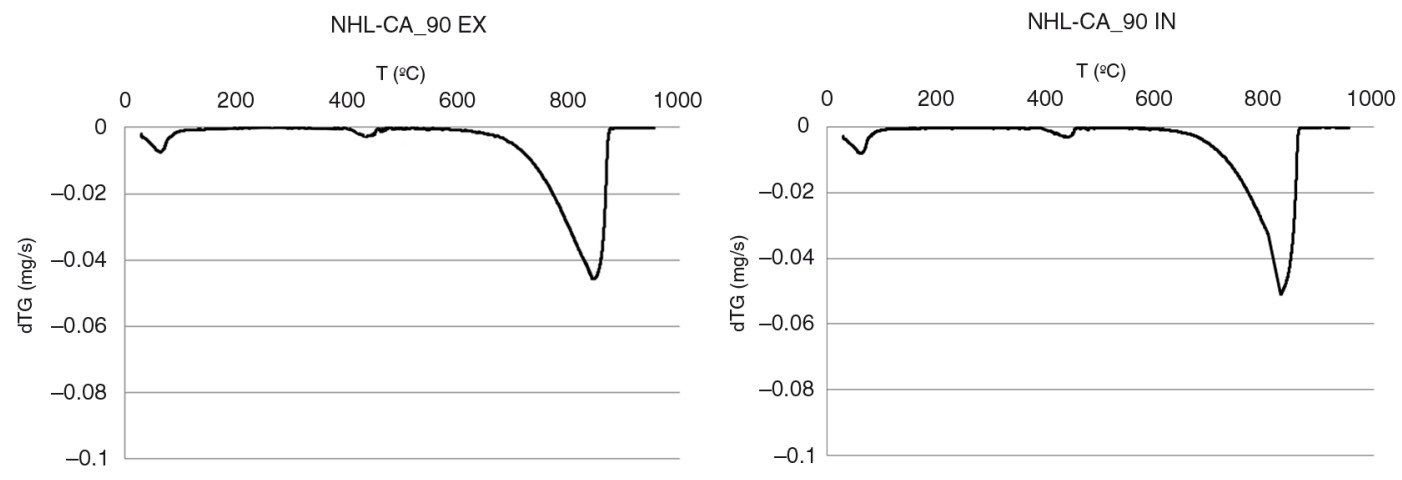

FIGURE 2. Differential thermal curves of the external (EX) and internal (IN) zones of mortars made with siliceous (NHL-SA) and calcareous (NHL-CA) sand and cured at a relative humidity of $90 \%$ (_90), where the differential weight loss (dTG, in $\mathrm{mg} / \mathrm{s}$ ) is represented as a function of the decomposition temperature $\left(\mathrm{T}\right.$, in $\left.{ }^{\circ} \mathrm{C}\right)$. 
From the observations on the amount of portlandite, calcium silicates and calcium silicate hydrates in the two types of mortars, at different relative humidity conditions, it is possible to state that:

- the carbonation process is faster at $60 \%$ than at $90 \%$ of $\mathrm{RH}$, whilst the contrary is observed for the hydration reaction;

- there are no significant differences between the external and the internal zones of NHL-CA mortars at both conditions of $\mathrm{RH}$;

- the external zone of NHL-SA mortars is more carbonated than the internal one at both conditions of relative humidity and, at $90 \%$ of $\mathrm{RH}$, a higher hydration (more hydrated silicates) is observed in the interior of samples.

\subsection{Textural study of mortars}

The morphology of the formed mineral phases and the texture of mortars were observed by means of FESEM.

In NHL-SA mortars a larger amount of hydrated phases is present (needle-like C-S-H, Figure 3a-c) compared to NHL-CA mortars (Figure $3 \mathrm{~d}-\mathrm{f}$ ), especially in those cured at $60 \%$ of $\mathrm{RH}$. In the latter, calcite crystals with different size and morphology were observed (Figure $3 \mathrm{f}$ and g). It is possible to recognize nanometric (with size smaller than $500 \mathrm{~nm}$, Figure $3 \mathrm{e}$ and $\mathrm{f})$ and micrometric $(1-3 \mu \mathrm{m}$, Figure 3f) calcite crystals with rhombohedral habit. In NHL-CA mortars, it is possible to see also portlandite crystals, untransformed or in process of transformation, and needle-like crystals of C-S-H (Figure 3f). Figure 3 also shows the EDX analysis carried out in some areas of the observed samples. The detection of Si in the first spectrum (Figure 3c) has to be attributed mainly to the quartz grain of the siliceous aggregate located just below the C-S-H needles.

The matrix of NHL-SA mortars presents a higher porosity compared to that of NHL-CA, at all values of $\mathrm{RH}$, as observed by FESEM (Figure 3a) and determined by means of MIP $\left(\mathrm{P}_{\mathrm{o}} \sim 27 \%\right.$, Table 4$)$. NHL-CA mortars present a compact texture (Figure 3d) and a porosity of approximately $25 \%\left(\mathrm{P}_{\mathrm{o}}\right.$, Table 4$)$. In NHL-SA mortars, instead, the increase of relative humidity leads to a slight decrease in the total porosity (around 2\% less), due to the formation of a larger quantity of hydrated phases in the internal zone of this mortar.

The real and bulk densities are slightly higher in NHL-CA mortars (Table 4), due to the different density of the minerals constituting the two types of mortars $\left(D_{\mathrm{r} \text { calcite }}=2.71 \mathrm{~g} / \mathrm{cm}^{3} ; D_{\mathrm{r} \text { dolomite }}=2.84 \mathrm{~g} / \mathrm{cm}^{3}\right.$; $D_{\text {r quartz }}=2.62 \mathrm{~g} / \mathrm{cm}^{3}$ ).

In the pore size distribution curves (Figure 4) two families of pores are observed: the main one, including pores with radii comprised between 0.05 and $3 \mu \mathrm{m}$, and the second smaller one, with pores of radii comprised between 0.005 and $0.05 \mu \mathrm{m}$. Both types of pores are mostly present in the matrix of mortars. Their volume is higher in NHL-SA mortars (Figure 4a), and this agrees with the higher values of open total porosity measured in this mortar compared to the NHL-CA one (Table 4). This is due, on the one hand, to the presence of a more porous matrix (Figure 3a) and, on the other hand, to the formation of a larger amount

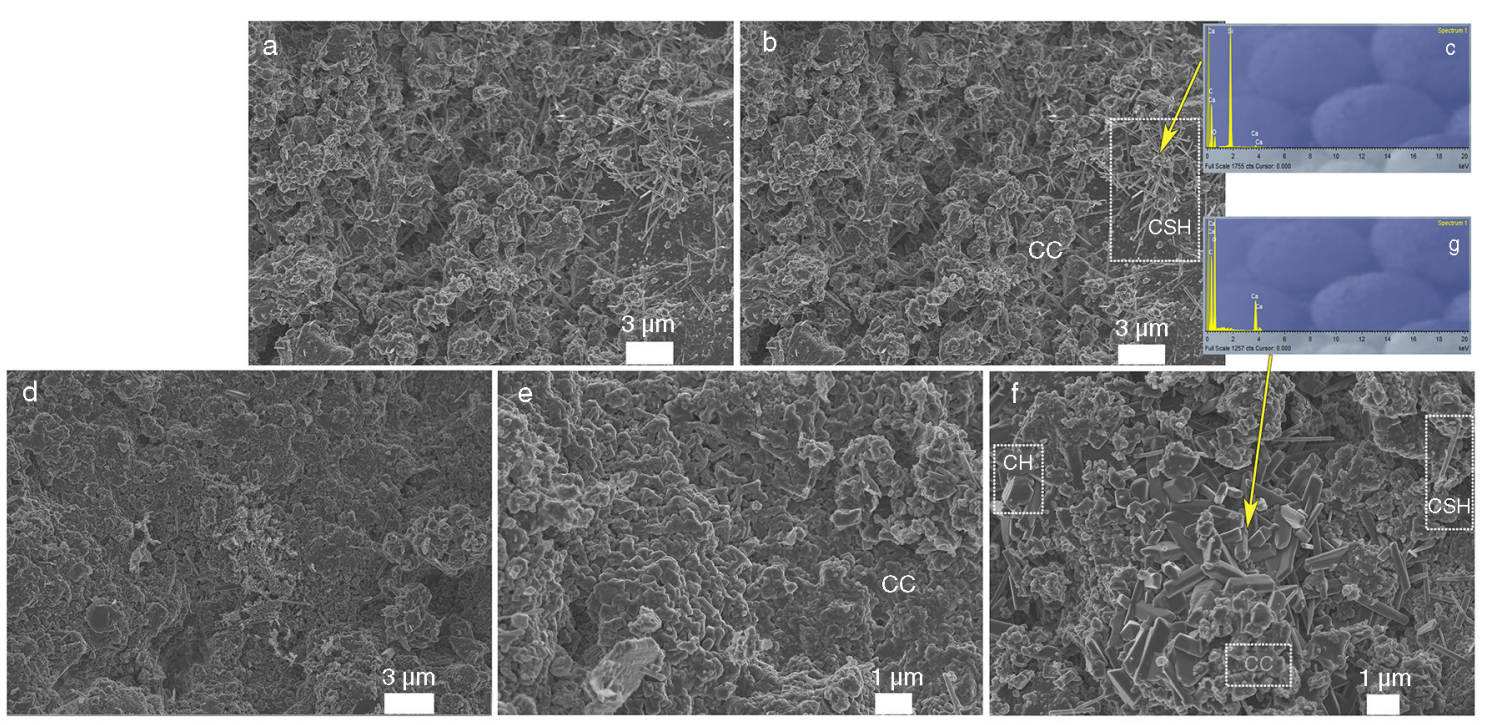

FIGURE 3. FESEM images of mortars made with siliceous (NHL-SA, $a, b$ ) and calcareous (NHL-CA, d-f) sand and cured at a relative humidity of $60 \%$. Images $\mathrm{c}$ and $\mathrm{g}$ are EDS spectra of the phases shown in $\mathrm{b}$ and $\mathrm{f}$, respectively. $\mathrm{CC}=$ calcite; $\mathrm{CH}=$ portlandite; $\mathrm{CSH}=$ calcium silicate hydrates. 
TABLE 4. Results of mercury injection porosimetry (MIP), mechanical tests, and ultrasound propagation and colour measurements performed on mortars made with standardized siliceous (NHL-SA) and calcareous (NHL-CA) sand and cured at a relative humidity of 60\% (_60) and $90 \%$ (_90), 28 days after their elaboration. $\mathrm{P}_{\mathrm{o}}=$ open porosity (in \%); $\mathrm{D}_{\mathrm{a}}=$ bulk density (in $\mathrm{g} / \mathrm{mL}$ ); $\mathrm{D}_{\mathrm{r}}=$ real density (in $\mathrm{g} / \mathrm{mL}$ ); $\mathrm{R}_{\mathrm{f}}=$ flexural strength (in $\mathrm{MPa}$ );

$\mathrm{R}_{\mathrm{c}}=$ compressive strength (in MPa); carbonation edge (in $\mathrm{mm}$ ); $\mathrm{V}_{\mathrm{p}}=\mathrm{P}$ waves propagation velocity (in $\mathrm{m} / \mathrm{s}$ ); $\mathrm{L}^{*}=$ lightness; $\mathrm{a}^{*} \mathrm{y} \mathrm{b}^{*}=$ chromatic coordinates; $\mathrm{W}=$ whiteness index; $\mathrm{Y}=$ yellow index

\begin{tabular}{lrrrr}
\hline Mortar & NHL-SA_60 & NHL-SA_90 & NHL-CA_60 & NHL-CA_90 \\
\hline MIP & & & & \\
$\mathrm{P}_{\mathrm{o}}$ & $28.3 \pm 0.6$ & $26.3 \pm 0.2$ & $24.9 \pm 2.7$ & $25.7 \pm 0.2$ \\
$\mathrm{D}_{\mathrm{r}}$ & $2.7 \pm 0.0$ & $2.7 \pm 0.0$ & $2.6 \pm 0.0$ & $2.6 \pm 0.0$ \\
$\mathrm{D}_{\mathrm{a}}$ & $1.9 \pm 0.1$ & $1.9 \pm 0.0$ & $2.0 \pm 0.1$ & $2.0 \pm 0.0$ \\
Mechanical tests & & & \\
$\mathrm{R}_{\mathrm{f}}$ & $0.1 \pm 0.09$ & $0.2 \pm 0.03$ & $0.2 \pm 0.09$ & $0.1 \pm 0.03$ \\
$\mathrm{R}_{\mathrm{c}}$ & $2 \pm 0.09$ & $2.8 \pm 0.09$ & $0.8 \pm 0.03$ & $1.7 \pm 0.06$ \\
Carbonation edge $^{\dagger}$ & & & & \\
mm & 1 & 0 & 1.5 & 0 \\
Ultrasound measurement & & & & \\
$\mathrm{V}_{\mathrm{p}}$ & $1420 \pm 60.0$ & $2044 \pm 72.50$ & $1456 \pm 71.25$ & $1725 \pm 37.50$ \\
Chromatic parameters & & & & \\
$\mathrm{L}^{*}$ & $43.39 \pm 0.59$ & $82.30 \pm 0.77$ & $83.89 \pm 2.08$ & $77.27 \pm 0.41$ \\
$\mathrm{a}^{*}$ & $0.87 \pm 0.18$ & $1.99 \pm 0.13$ & $2.04 \pm 0.25$ & $3.76 \pm 0.12$ \\
$\mathrm{~b}^{*}$ & $2.35 \pm 0.64$ & $8.93 \pm 0.50$ & $7.18 \pm 1.00$ & $12.67 \pm 0.53$ \\
$\mathrm{~W}$ & $23.98 \pm 2.13$ & $24.11 \pm 2.49$ & $32.85 \pm 5.92$ & $5.75 \pm 1.94$ \\
$\mathrm{Y}$ & $3.90 \pm 0.99$ & $15.37 \pm 0.83$ & $12.23 \pm 1.77$ & $22.43 \pm 0.91$ \\
\hline
\end{tabular}

${ }^{\dagger}$ It has been measured only on the face exposed to air for the first 7 days in the mould.
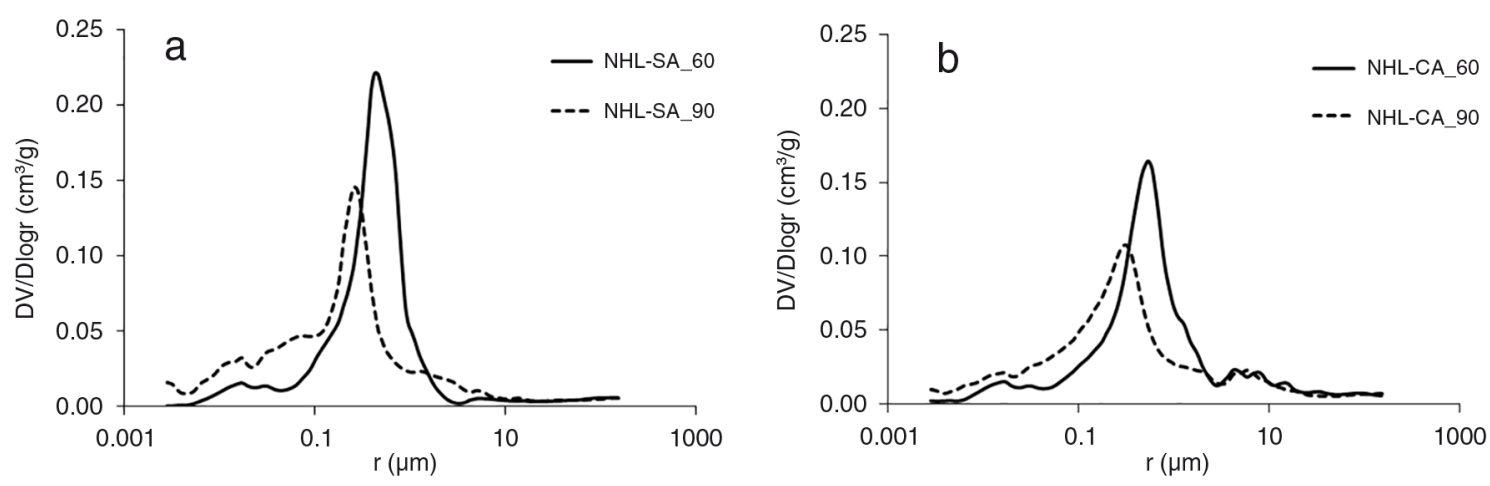

FIGURE 4. Porosimetric curves of mortars made with siliceous (NHL-SA, a) and calcareous (NHL-CA, b) sand and cured at a relative humidity of $60 \%(60)$ and $90 \%\left(\_90\right)$. Access pore radius (r, in $\left.\mu \mathrm{m}\right)$ is represented as a function of the incremental volume (DV/Dlogr, in $\mathrm{cm}^{3} / \mathrm{g}$ ).

of C-S-H, which create a higher volume of micropores of small size (Figure 3b).

In mortars cured at $90 \%$ of $\mathrm{RH}$, both the pore size (the main peak has moved between 0.1 and $1 \mu \mathrm{m}$, Figure 4) and the pore volume are reduced, due to the formation of a larger amount of hydrated phases, as observed by means of FESEM and determined by TGA (Table 3 ).

Despite the higher porosity of the matrix of NHL-SA mortar, a better adhesion exists between the matrix and the aggregate grains (Figure 5a), with respect to NHL-CA mortar (Figure $5 b$ ). The porosity in the contact zone between the matrix of NHL-CA and the calcareous grains of biggest size $(6 \mathrm{~mm})$ can be observed in the highlighted zone in Figure 5b; this contact is more evident than in NHL-SA mortar. According to MIP analysis, those pores have a radius comprised between 3 and $20 \mu \mathrm{m}$ (Figure 4) and their volume, indeed, is higher in NHL-CA mortar samples (Figure 4b). 

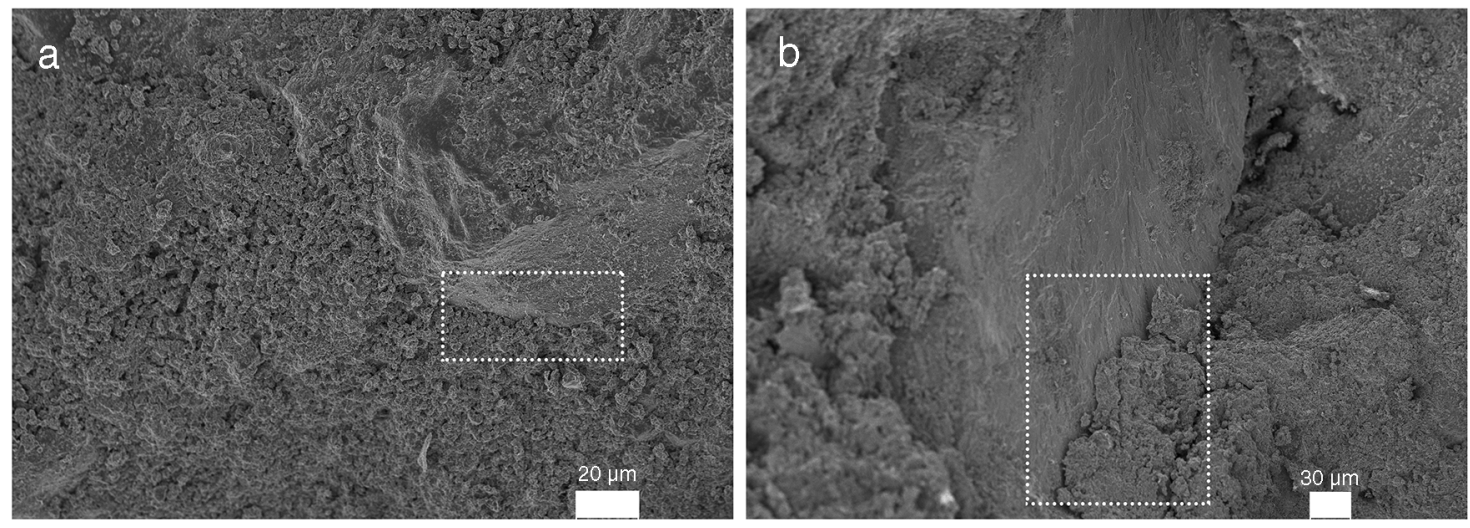

FIGURE 5. FESEM images of the contact between aggregate grains and matrix in mortars made with siliceous (NHL-SA, a) and calcareous (NHL-CA, b) sand and cured at a relative humidity of $90 \%$.

\subsection{Mechanical tests}

Values of flexural and compressive strength of the two mortar types cured at $60 \%$ and $90 \%$ of relative humidity for 28 days are presented in Table 4. NHL-SA mortars present higher values of compressive strength and similar values of flexural strength compared to NHL-CA mortars. The higher compressive strength of the former is especially related to the higher hardness of the quartz crystals and to the better adhesion between matrix and aggregate, as observed by FESEM (Figure 5).

As expected, due to the larger formation of hydrated phases and the lower porosity, mortars cured at $90 \%$ of $\mathrm{RH}$ present the highest values of $\mathrm{R}_{\mathrm{c}}$, as already observed by other authors (21). However, the measured $R_{c}$ values do not reach $3 \mathrm{MPa}$, value that is under the expected one in mortars made with NHL3.5 and exposed to $90 \%$ of relative humidity (22).
This is due to the fact that the mechanical properties of a mortar do not depend only on the class of the lime (in this case 3.5) but also on other factors, such as aggregate type, water-to-binder and binderto-aggregate dosages, among others. In particular, mortars prepared with calcareous aggregate do not reach the expected values of mechanical strength due to the porosity of the aggregate, which increases the water demand during mixing (see the water-to-binder dosage in Table 2).

After the flexural rupture, phenolphthalein was sprayed on the broken surfaces to observe the progress of carbonation in mortars. The carbonation edge was approximately $1 \mathrm{~mm}$ in both types of mortars cured at $60 \%$ of $\mathrm{RH}$, whilst those cured at $90 \%$ of $\mathrm{RH}$ did not present a well-defined carbonation edge (Table 4, Figure 6). The hydrated phases formed have an alkaline $\mathrm{pH}$, therefore phenolphthalein keeps its pink colour and it is not
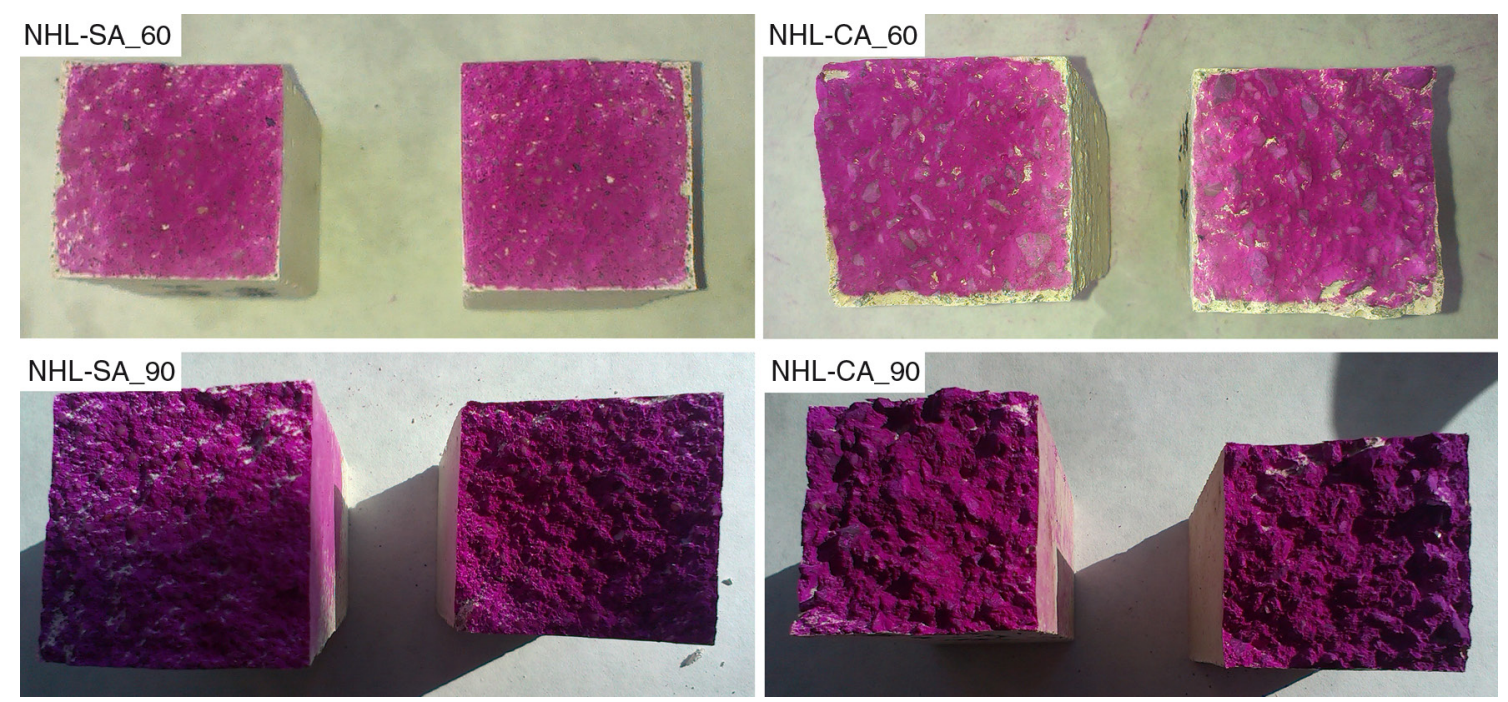

FIGURE 6. Mortars made with siliceous (NHL-SA) and calcareous (NHL-CA) sand and cured at a relative humidity of $60 \%$ and $90 \%$, sprayed with phenolphthalein after the flexural rupture. 


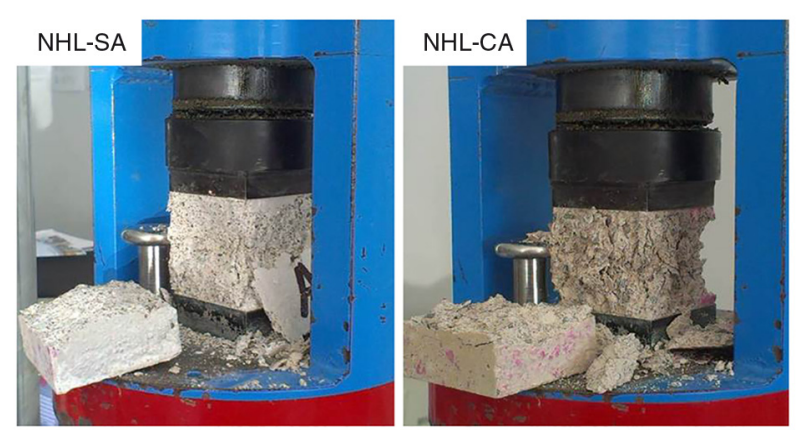

Figure 7. Appearance of mortars made with siliceous (NHL-SA) and calcareous (NHL-CA) sand and cured at a relative humidity of $90 \%$, after the compressive rupture.

possible to distinguish them clearly, although these phases are present in the mortar, as observed by means of FESEM. This demonstrates that hydration of hydraulic lime is the predominant process at $90 \%$ of RH and in the interior of samples (which shows a pink colour, Figure 6), whilst carbonation is more favoured at lower relative humidity and in the exterior of samples (which shows a neutral colour, Figure 6).

The way in which samples break during compressive rupture is characteristics because, under a compressive stress perpendicular to the compaction plane, the first layers that come off the mortar are the most superficial ones (Figure 7). This indicates that there exists a discontinuity in the compressive strength between the external zone, more carbonated, and the internal one, richer in hydrated phases $(23,24)$. NHL-CA mortars are less resistant to compression compared to NHL-SA ones, to such extent that the pressure exerted gives place to a partial breaking down of samples, especially in the contact zone between the matrix and the biggest aggregate grains (Figure 7).

\subsection{Non-destructive tests}

Mortars cured at $90 \%$ of relative humidity present higher values of ultrasound velocity than those cured at $60 \%$ of RH (Table 4 ). The former, indeed, have lower porosity, as indicated by MIP analyses (Table 4). It is worth mentioning that in NHL-SA mortars it was possible to measure the propagation velocity of ultrasounds along the longest edge $(16 \mathrm{~cm})$ of the samples, parallel to the compaction plane. The velocity measured in this direction was $608 \mathrm{~m} / \mathrm{s}$, very low compared to the other measured values (between 1400 and $2050 \mathrm{~m} / \mathrm{s}$, Table 4). In the rest of samples, instead, this measurement did not provide any value, since the velocity of waves was under the detection limit of the transducers used. The fact that velocity along the longest edge was measured only in NHL-SA samples and that this mortar presents the highest $\mathrm{V}_{\mathrm{p}}$ values, once again depends on the better adhesion between matrix and aggregate with respect to NHL-CA mortar. The velocity of propagation of ultrasounds through a mortar decreases and the spatial attenuation increases considerably when the wave propagates from an aggregate grain to the matrix, due to differences of mineralogy and, especially, porosity (25). Moreover, if the wave finds a void between the grain and the matrix its velocity decreases more, since it is travelling from a solid medium of higher density (the aggregate grain) through a gaseous medium (the pore), and finally, to a solid medium of lower density (the matrix), as it occurs in NHL-CA mortars.

The chromatic parameters $\mathrm{L}^{*}, \mathrm{a}^{*}, \mathrm{~b}^{*}, \mathrm{~W}$ and $\mathrm{Y}$ of mortars are presented in Table 4 . The mortars with higher lightness are NHL-CA cured at $60 \%$ and NHL-SA cured at $90 \%$ of RH (in both, $\mathrm{L}^{*}$ \%3). NHL-CA mortars become slightly darker at a condition of high relative humidity ( $\mathrm{L}^{*} \mathrm{y} \mathrm{W}$ at $90 \%$ of RH, Table 4 ). The presence in this mortar of calcareous aggregate grains of dark grey colour gives a darker appearance to samples, compared to NHL-SA. In the latter, the smoother rounded texture of the siliceous grains and the higher reflectivity of the quartz crystals produce a higher lightness in the mortar. $a^{*}$ and $b^{*}$ values indicate a slight tendency of the mortar colour toward yellow, especially in NHL-CA, as also the yellow index indicates (Y, Table 4).

\section{CONCLUSIONS}

The chemical-mineralogical, textural and physicalmechanical properties of two types of mortars produced with a natural hydraulic lime and two aggregates of calcareous and siliceous composition, cured at $60 \%$ and $90 \%$ of relative humidity, were studied here.

This study has shown once again that the prior characterization of the raw materials and the mortars destined to restoration works is fundamental for a correct intervention. Moreover, the importance of selecting adequate curing conditions, investigating their influence in the development of the mineral phases, porous system, compactness, mechanical resistance and also colour of mortars has been highlighted.

It has been demonstrated that the use of a natural hydraulic lime in repair mortars is suitable and can lead to good results in the building, provided that mortars are produced with an aggregate of adequate composition and grading and are cured under a relative humidity of $90 \%$ (which can be achieved periodically wetting the mortar, according to the real atmospheric conditions). Regarding the aggregate, it has been found that a calcareous one favours a faster hardening and gives place to a lower porosity, although it would be appropriate to 
select a finer grain size (smaller than $6 \mathrm{~mm}$ ), so as to achieve better textural and mechanical properties in the mortar.

\section{ACKNOWLEDGEMENTS}

This study was financially supported by the Spanish research group RNM179 of the Junta de Andalucía, by the research project MAT-2012-34473 and by the Institute of Conservation and Restoration of Cultural Heritage of the CICOP foundation (ICON-CICOP). We are grateful to FYM Italcementi enterprise (Malaga, Spain) for supplying the hydraulic lime and providing data about it. We also thank the $\mathrm{CECH}$ laboratory (Granada, Spain) for supplying the aggregates and contributing to the preparation and curing of mortars.

\section{REFERENCES}

1. UNE-EN 459-1 (2011) Cales para la construcción. Parte 1: Definiciones, especificaciones y criterios de conformidad. AENOR, Madrid.

2. Hartshorn, S.A.; Sharp, J.H.; Swamy, R.N. (1999) Thaumasite formation in Portland-limestone cement pastes. Cem. Concr. Res. 29, 1331-1340. http://dx.doi.org/10.1016/ S0008-8846(99)00100-3.

3. Veniale, F.; Setti, M.; Rodriguez-Navarro, C.; Lodola, S.; Palestra, W.; Busetto, A. (2003) Thaumasite as decay product of cement mortar in brick masonry of a church near Venice. Cem. Concr. Compos. 25, 1123-1129. http://dx.doi. org/10.1016/S0958-9465(03)00159-8

4. Henry, A.; Stewart, J. (2011) Mortars, renders and plasters. English Heritage, Practical Building Conservation. B. Martin C. Wood (eds.). Ashgate Publishing Limited, Farnham (UK), 126, 154-155, 248-252.

5. Draft BS EN 16572 (2013) Conservation of Cultural Heritage - Glossary of technical terms concerning mortars for masonry, renders and plasters used in cultural heritage. Bsi, London.

6. Boletín 023 (2005) Morteros, Guía General. AFAM, Madrid, 19

7. UNE-EN 1015-11 (2002) Método de ensayo de los morteros de albañilería. Parte 11: Determinación de la resistencia a flexión y a compresión del morteros endurecido. AENOR, Madrid.

8. Arizzi A.; Molina E.; Cultrone G. (2015) Repair rendering mortars for the restoration of the Vargas Palace in Granada (Spain): a comparative study of the mortar behaviour in the laboratory and on site. R. Prikryl, A. Torok, M. GomezHeras, K. Miskovsky, M. Theodoridou (eds.). Sustainable Use of Traditional Geomaterials in Construction Practice. Geological Society, London, Special Publications, 416. http://dx.doi.org/10.1144/SP416.2

9. Cachim, P.; Velosa, A.L.; Rocha, F. (2010) Effect of Portuguese metakaolin on hydraulic lime concrete using different curing conditions. Constr. Build. Mater. 24, 71-78. http://dx.doi.org/10.1016/j.conbuildmat.2009.08.010.

10. UNE-EN 196-1 (2000) Métodos de ensayo de cementos. Determinación de la resistencia mecánica, a una edad determinada de una muestra de cemento. AENOR, Madrid.

11. Martin, J.D. (2004) XPowder. A software package for powder X-ray diffraction analysis. Dep. Leg. M-11719.

12. Vera, J.A.; Ancochea, E.; Barnolas, A.; Bea, F.; Calvo, J.P.; Civis, J.; De Vicente, G.; Fernández Gianotti, J.; García Cortés, A.; Pérez Estaún, A.; Pujalte, V.; Rodríguez Fernández, L.R.; Sopeña, A.; Tejero, R. (2004) Geología de España. Ed. J.A. Vera, SGE-IGME, Madrid (Spain).

13. Cardell, C. (2003) Cristalización de sales en calcarenitas: aplicación al monasterio de San Jerónimo, Granada. Tesis Doctoral, Universidad de Granada.

14. UNE-EN 1015-2 (1999) Métodos de ensayo de los morteros para albañilería. Parte 2: Toma de muestra total de morteros y preparación de los morteros para ensayo. AENOR, Madrid.

15. Cazalla, O. (2002) Morteros de cal. Aplicación en el Patrimonio Histórico. Tesis doctoral Universidad de Granada.

16. Luque, A. (2005) La cal en Andalucía y su aplicación en el Patrimonio Histórico Arquitectónico. Trabajo de Investigación Tutelada, Universidad de Granada.

17. UNE-EN 1015-3 (1999) Método de ensayo de los morteros de albañilería. Parte 3: Determinación de la consistencia del mortero fresco (por la mesa de sacudidas). AENOR, Madrid.

18. UNE-EN 459-2 (2011) Cales para la construcción. Parte 2: Métodos de ensayo. AENOR, Madrid.

19. Mertens, G.; Madau, P.; Durinck, D.; Blanpain, B.; Elsen, J. (2007) Quantitative mineralogical analysis of hydraulic limes by X-ray diffraction. Cem. Concr. Res. 37, 1524-1530. http://dx.doi.org/10.1016/j.cemconres.2007.08.002.

20. Lawrence, R.M.H.; Mays, T.J.; Walker, P.; D'Ayala, D. (2006) Determination of carbonation profiles in nonhydraulic lime mortars using thermogravimetric analysis. Thermochim. Acta 444, 179-189. http://dx.doi.org/10.1016/j. tca.2006.03.002

21. Papayianni, I.; Stefanidou, M. (2006) Strength-porosity relacionship in lime-pozzolan mortars. Constr. Build. Mater. 20, 700-705. http://dx.doi.org/10.1016/j.conbuildmat.2005. 02.012 .

22. Lanas, J.; Pérez, J.L.; Bello, M.A.; Álvarez, J.I. (2004) Mechanical properties of natural hydraulic lime-based mortars. Cem. Concr. Res. 34, 1291-2201. http://dx.doi. org/10.1016/j.cemconres.2004.02.005.

23. Benavente, D.; Martinez-Martinez, J.; Jauregui, P.; Rodriguez, M.A.; Garcia del Cura, M.A. (2006). Assessment of the strength of building rocks using signal proccessing procedures. Constr. Build. Mater. 20. 562-568. http:// dx.doi.org/10.1016/j.conbuildmat.2005.01.043.

24. Arizzi, A.; Martínez-Martínez, J.; Cultrone, G.; Benavente, D. (2011) Mechanical evolution of lime mortars during the carbonation process. Key Eng. Mat. 465, 483-486. http:// dx.doi.org/10.4028/www.scientific.net/KEM.465.483.

25. Arizzi, A.; Martinez-Martinez, J.; Cultrone, G. (2013) Ultrasonic wave propagation through lime mortars: an alternative and non-destructive tool for textural characterization. Mater. Struct. 46 [8], 1321-1335. http://dx.doi. org/10.1617/s11527-012-9976-1. 